\title{
Role of science-based and adaptive management in allocating environmental flows to the Nueces Estuary, Texas, USA
}

\author{
P. A. Montagna ${ }^{1}$, E. M. Hill ${ }^{2} \&$ B. Moulton ${ }^{3}$ \\ ${ }^{1}$ Harte Research Institute for Gulf of Mexico Studies, USA \\ ${ }^{2}$ Center for Coastal Studies, Texas A\&M University - Corpus Christi, \\ USA \\ ${ }^{3}$ Dripping Springs, USA
}

\begin{abstract}
The Nueces River System has been subject to adaptive management since construction of the Choke Canyon Reservoir in 1982. A special condition required the City of Corpus Christi to provide not less than 185 million cubic meters $(151,000 \mathrm{ac}-\mathrm{ft})$ of water per year to the Nueces Estuary through a combination of spills, releases, and return flows to maintain ecological health and productivity of living marine resources. However, no releases were made and salinities in Nueces Bay increased to hypersaline conditions during the drought period of 1988-1990 and the estuary was inverted where fresher water entered the delta on high tides. In contrast, the bay historically supported populations of shrimp and oysters generally requiring salinities in the range of 10-20 ppt. Beginning in May 1990, the Texas Water Commission issued a series of Orders requiring the City to meet the special conditions contained in their water right permit and provide for freshwater inflows to the estuary. Since 1990, a series of restoration activities, monitoring and experimental studies, and Order amendments has resulted in a stakeholder driven process that increased environmental health while providing a sustainable water supply to the region. However, with climate change and continued development, more changes are likely to occur in the future. The lesson learned is that the goal of achieving consensus can occur with a blend and balance of science and a stakeholder decision process.
\end{abstract}

Keywords: freshwater inflow, wetlands, marsh, shellfish, dams, water resources. 


\section{Introduction}

The Clean Water Act of 1972 addressed broadly water quality within the United States (US), yet to date there are no federal laws regulating water quantity to protect the environment, which is called environmental flows. There are three types of environmental flows: 1) instream flows with rivers and streams, 2) inflows from rivers to bays and estuaries, and 3) outflows from rivers directly into the ocean and onto continental shelves. An estuary is a transition zone where salt water from the sea mixes with fresh water from rivers. Freshwater inflow serves a variety of important functions to coastal estuarine ecosystems by creating and preserving low-salinity nurseries, transporting sediments, nutrients, and allochthonous organic matter downstream, and affecting estuarine species movements and reproductive timing (Longley [4]). However, dewatering of estuaries is occurring principally because of human alteration of watersheds and river flows. Between 1960 and 2000, the volume of water in global reservoirs quadrupled, the volume of water withdrawn from rivers and lakes doubled, and currently $60 \%$ of the Earth's runoff is captured [1]. The effects of altered inflows into coastal ecosystems have been enormous (see compilations in [2] and [3]).

Although it is a concern of federal, state, and local agencies, few jurisdictions have laws regulating environmental flows. Texas and Florida are two notable exceptions where state laws exist to manage environmental flows [3]. In response to drought, the Texas Legislature enacted the Texas Water Planning Act of 1957, which called for consideration of bays and estuaries in the upstream water planning process [4]. The first Texas Water Plan published in November 1968 called for $2.510^{6}$ acre-feet $\left(3.0810^{9} \mathrm{~m}^{3}\right)$ of freshwater inflows annually to the Texas bays and estuaries. In 1985, the Legislature amended the water code to require new water permits to consider the "conditions considered necessary to maintain beneficial inflows to any affected bay or estuary system." Beneficial inflows are defined as the salinity, nutrients, and sediment loading regime adequate to maintain a sound ecological environment.

Although the requirements for environmental flows to the coast have a long history in Texas, there were no test cases until 1990. Construction of the Choke Canyon Reservoir was completed in 1982 and after filling in 1987, the City of Corpus Christi was required to provide not less than 151,000 ac-ft $\left(18510^{6} \mathrm{~m}^{3}\right)$ of fresh water per year to the Nueces Estuary to maintain ecological health and productivity of living marine resources. However, no releases were made and Nueces Bay became hypersaline during the drought of 1988 - 1990. After public complaints, the Texas Water Commission issued a series of orders beginning in May 1990 requiring the City to meet the special conditions contained in their water right permit that required provision of freshwater inflows to the estuary. However, there were many questions that needed to be answered. What was the right quantity? What were the most effective ways to provide the water? And, what was the role of stakeholders? Without knowing the jargon, the initial 1990 order set in motion a series of stakeholder driven, science-based, adaptive management actions to protect environmental flows. 


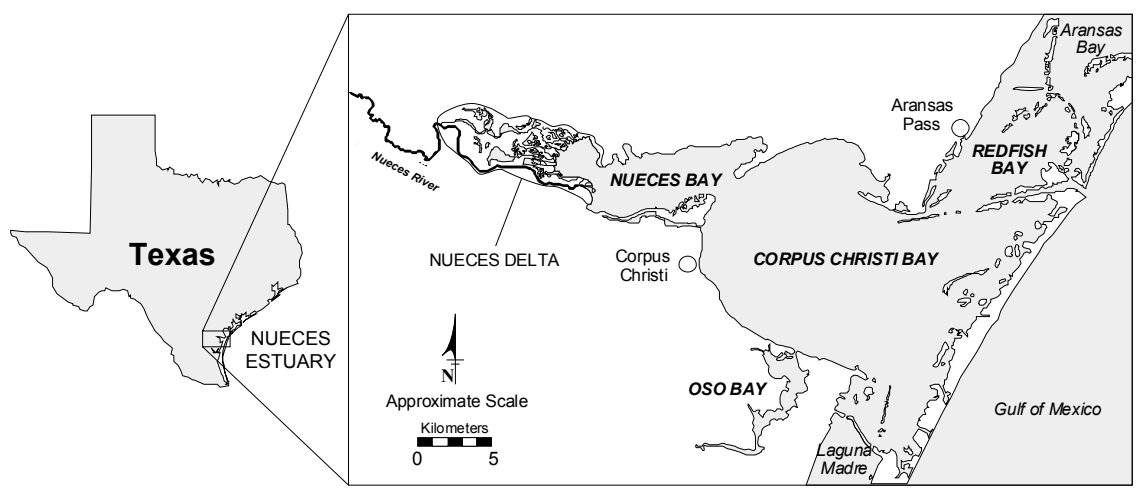

Figure 1: $\quad$ Location of the Nueces Delta [5].

\section{Background}

\subsection{Nueces River, Delta, and Estuary}

Nueces Estuary is one of seven major estuarine systems along the Texas Coast. The Nueces Estuary includes the marsh system in Nueces Delta, Nueces River tidal segment, one primary bay Corpus Christi Bay (connected to the Gulf of Mexico by Aransas Pass), one secondary bay Nueces Bay (that connects the river and delta to the primary bay), and two tertiary bays Oso and Redfish Bay, fig. 1. The Nueces River Saltwater Barrier Dam, located adjacent to IH 37, was originally constructed in 1898 to restrict saltwater intrusion to the upstream nontidal segment of the river. The Nueces Estuary is odd in that the Nueces River runs parallel to and on the south side of the Nueces Delta and the river empties in to Nueces Bay below the delta. Rincon Bayou is a creek connecting to the tidal segment of the Nueces River to the delta during flood events, and the bayou runs down the main stem of the Nueces Delta.

The Nueces Delta is located in a semi-arid, sub-tropical climate region characterized by hot, humid summers, and mild winters with occasional freezes $[5,6]$. Mean annual precipitation for the Nueces Delta is approximately $76 \mathrm{~cm}$ $\mathrm{yr}^{-1}$. Mean annual evaporation rates typically average from 90 to $115 \mathrm{~cm} \mathrm{yr}^{-1}$, but may be as high as $150 \mathrm{~cm} \mathrm{yr}^{-1}$ during time of drought. Typically, the delta experiences a net annual moisture loss of approximately $31 \mathrm{~cm} \mathrm{yr}^{-1}$.

\subsection{Alterations}

A complete history of the Corpus Christi water supply system is found in Cunningham [7]. Briefly, the Nueces River provides fresh water for the City of Corpus Christi and surrounding Coastal Bend area. The La Fruta Dam, built in 1935, was the first dam on the Nueces River impounding Lake Corpus Christi. La Fruta Dam had a storage capacity of approximately 55,000 acre- $\mathrm{ft}\left(6810^{6} \mathrm{~m}^{3}\right)$ and was replaced in 1958 with the current dam, Wesley Seale Dam which has a current water storage capacity of 257,260 acre- $\mathrm{ft}\left(31710^{6} \mathrm{~m}^{3}\right)$. The Choke 
Canyon Reservoir built in 1982 has a storage capacity of 695,271 acre-ft (851 $10^{6} \mathrm{~m}^{3}$ ), and is located at the confluence of the Frio River and Nueces River. Lake Corpus Christi and Choke Canyon Reservoirs, located $40 \mathrm{~km}$ and $100 \mathrm{~km}$ upriver, respectively, control approximately $98.0 \%$ of the flow from the Nueces River Basin and regulate freshwater inflows into the Nueces Estuary [8].

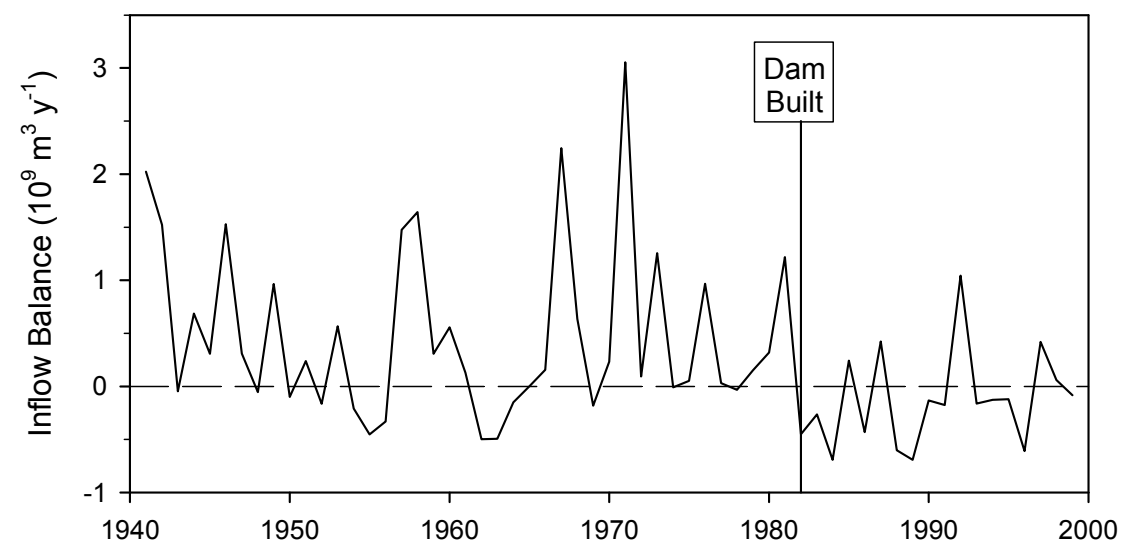

Figure 2: Average annual net inflow balance into Nueces Bay [10].

Construction of the dams on the Nueces River reduced freshwater inflows to the estuary by about $48 \%$ [9]. An ecologically important method to measure flows is inflow balance, i.e., the net water remaining after all diversions and evaporation is subtracted. Average annual flows from Nueces River to Nueces Bay varied from 1940 to 1982 , but were mostly net positive, fig. 2. In contrast, net flows decreased after Choke Canyon Dam was built in 1982 and were mostly net negative. Thus, the Nueces Estuary was transformed from a neutral to positive estuary to a negative estuary. The timing of flows was also altered. There were two peak flow months prior to 1982 and the positive nature of the estuary was largely due to spring and fall inflow events, fig. 3 . The hydrograph of average monthly flows flattened after 1983 and the estuary was neutral during spring and fall and negative during the summer.

The change in flow caused a large change in the average annual salinity, fig. 4. Between 1976 and 1982, the average annual salinity in Nueces Bay was always less than 26 ppt. Between 1983 and 2002, average annual salinities were below 26 ppt in only 5 out of 19 years.

While many estuarine fauna and flora are able to tolerate periods of hypersaline conditions, prolonged hypersalinity in the Nueces Delta reduced biological productivity, vegetation cover, species richness, and species diversity [11-13]. Elevated salinity also adversely affects commercially and recreationally important faunal species including shellfish, i.e., shrimp and oyster populations $[4,14]$. Historically, Nueces Bay supported populations of shrimp and oysters, fig. 4, which generally requires salinities in the range of 10-20 ppt. Salinity increased to hypersaline conditions ( $>36 \mathrm{ppt}$ ) during the drought period 


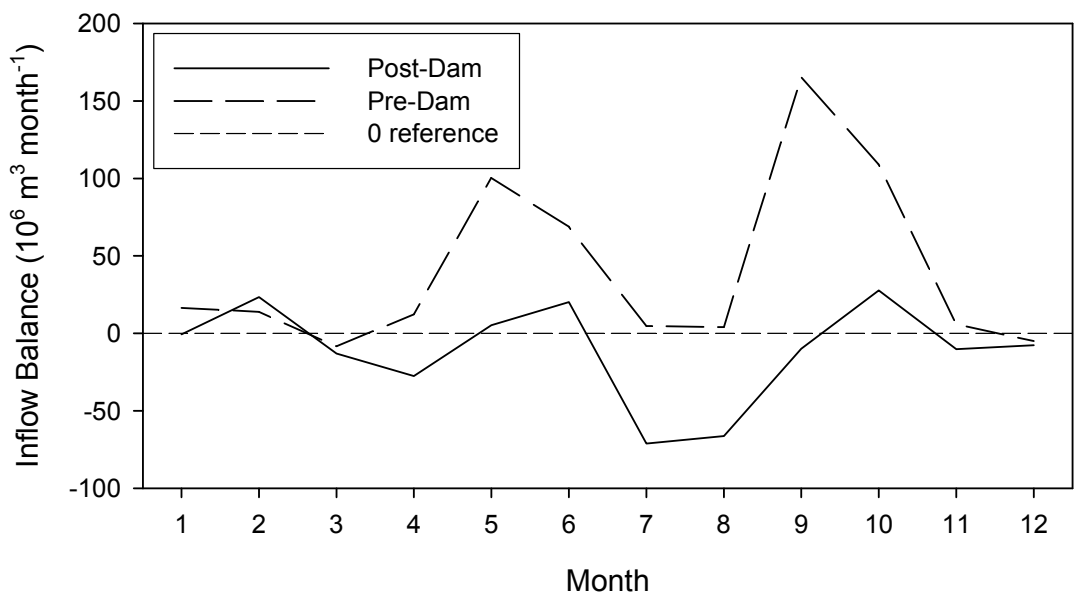

Figure 3: $\quad$ Average monthly inflow balance into Nueces Bay [13].

of 1988-1990, and consequently reduced the shrimp and oyster populations. In fact, it was the decline of shellfish harvest in Nueces Bay that prompted action by the State of Texas.

\section{Science-based management actions}

\subsection{Rincon Bayou demonstration project}

The Nueces River channel bypasses the Nueces Delta and conveys nearly all freshwater inflows directly into Nueces Bay. In the past, the Nueces Delta flooded often via a connection with Rincon Bayou. Because of natural processes the banks of the river are high, but based on historical accounts the delta flooded frequently and was characterized as a swamp [8]. By the 1990's it became evident that watershed modifications, alterations to the riverbanks, and increased urbanization along the Nueces River, had reduced overbanking to the delta to only rare flooding events once every three years [15].

At the time, the Nueces Delta was a reverse estuary where freshwater entered the delta, not from the river, but on high tidal flows from the bay, and it was often hypersaline because of evaporation [15]. However, there is fossil evidence that the Nueces Delta was historically a very low salinity area. During earlier studies [11], large middens of the clam Rangia cuneata were found.

The brackish clam, $R$. cuneata has long been recognized as the dominant benthic animal in the $0-15 \mathrm{ppt}$ salinity zone [16]. Therefore, $R$. cuneata is an indicator species to reconstruct the low-salinity habitat during the past. The shells are all broken in ways that indicate that the clams were used as food by native populations. The shells found in the Nueces Delta were large (mean 51 $\mathrm{cm}+1.6 \mathrm{~cm}$ ), and likely around 5 years old based on length-age formulas [17]. The maximum life span of Rangia is 15-20 years. The middens indicate that the historical freshwater inflow regime was sufficient to maintain low salinities in 


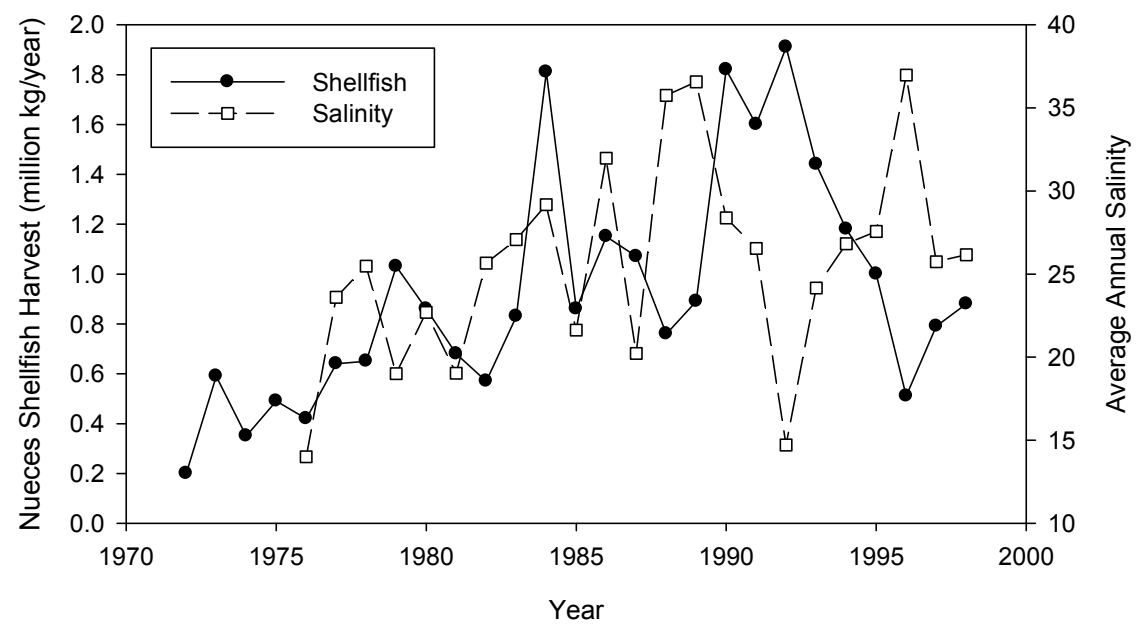

Figure 4: Average annual shellfish harvest and salinity in Nueces Bay.

the Delta in the past. Salinities in the $0-15$ ppt range are necessary to induce spawning, and embryos and early larvae survive only in the range of 2-15 ppt. Although there were large populations of Rangia in the past, the recent change in salinity resulted in complete loss of the population, as none were found in a recent 6-year study [11].

In October 1995, the U.S. Bureau of Reclamation [8] constructed a demonstration project to open an overflow channel dug to a depth of $1.0 \mathrm{ft}-\mathrm{msl}$ from the Nueces River to Rincon Bayou, which is the main stem channel of the Nueces Delta marsh. The purpose of the overflow channel was to increase opportunities for freshwater inflow into the delta to improve ecological value of the marsh. The project was very successful improving hydrology [15] by restoring the number of overflow events from one in three years to three in each year; however, the historical volumes of the floods were not restored. At first, the initial flooding events actually increased salinity because of the large amount of salt that had evaporated in the delta over the years. By 1997, the restored flow began to reduce salinities in the delta during floods. The reduced salinities led too reduced increased productivity of the marsh and living resources [11-13]. However, because this demonstration project did not have permanent easements and additional easements could not be obtained, the channel was closed in September 2000.

\subsection{Overflow channel reopening}

Largely based on the environmental benefits measured by the research performed in the Rincon Bayou Demonstration Project, the City of Corpus Christi rebuilt the overflow channel to divert water from the Nueces River to the upper reaches of Rincon Bayou. The second channel was constructed in October 2001. 


\subsection{Calallen pipeline diversion}

Because the overflow channel could deliver water to the delta only during floods, new plans were developed to try and deliver water on a more continuous basis. The Calallen Pool is upriver behind the salt water dam, and separates the tidal portion of the river from fresh water. The saltwater dam overflows only during rain events or releases. So that fresh water would enter the marsh on a continuous basis, a pipeline would be needed to divert water to the upper Rincon Bayou. The pipeline was planned to pass-through the first 3,000 acre-ft/month from Calallen Pool to Rincon Bayou each month that pass-through was required. The pipeline was supposed to be complete by 2004 , but there were years of delays because of difficulty obtaining necessary easements and poor weather. Construction of the pipeline was finally complete in 2008, but as of March 2009, the pipeline has not been fully operational.

\subsection{Allison Wastewater Treatment Plant diversion}

The City can receive environmental flow credit for return flows, so stakeholders recommended research on the effects of treated effluent diversions into the marsh. The City of Corpus Christi built a pipeline under the Nueces River to deliver secondary treated municipal wastewater effluent from the Allison Wastewater Treatment Plant to alleviate hypersaline and dry conditions and provide a nutrient-rich freshwater source in the lower Nueces Delta. The effluent discharges were approximately $2.010^{6}$ gallons $\mathrm{d}^{-1}\left(7,570 \mathrm{~m}^{3} \mathrm{~d}^{-1}\right)$ into a marsh site located in the Lower Nueces River Delta $\left(27^{\circ} 51.5^{\prime} \mathrm{N}, 97^{\circ} 33.6^{\prime} \mathrm{W}\right)$, fig. 2. Three earthen cells $(1.3$ ha each) were constructed to receive treated effluent in August 1997, the diversion began October 1998, and is ongoing.

The AWTP project enhanced avian habitat by providing a freshwater refuge to resident and migratory birds during drought conditions [18]. The diversion alleviated dry, hypersaline conditions, increased vegetation cover, and plant species richness [19]. Wastewater nitrogen was being assimilated into plant tissue at the diversion site, but soil pore water nitrogen was not significantly different from nearby sites $[13,19]$. However, the diversion volumes were not favorable for increasing plant species richness and the dominant species, Borrichia frutescens, increased in coverage because of lower salinity caused by freshwater, but not from the wastewater nitrogen source previously thought [20]. The biological effects were localized at the diversion point.

\section{Adaptive management actions}

The Nueces Estuary experienced a downward trend of annual stream flow volumes in the Nueces River near Mathis, Texas for 57 years (1940 - 1996) [9]. Both the water rights permit and operation plan for the water system have changed substantially since the original permit for construction of the Choke Canyon Reservoir was issued in 1976. The original certificate contained a special condition that required scheduled releases together with return flows to 
the estuary to maintain the "proper ecological environment and health of related living marine resources." Originally, the required release amount was not less than 151,000 ac-ft $\left(18510^{6} \mathrm{~m}^{3}\right)$ per year. The dam was completed in 1982 , but did not fill until June 1987 . In 1988 only 60,888 ac-ft $\left(7510^{6} \mathrm{~m}^{3}\right)$ flowed to the estuary and in 1989 only 67,551 ac-ft $\left(8210^{6} \mathrm{~m}^{3}\right)$ flowed to the estuary. In response, a local shrimper organization filed a complaint with the Texas Water Commission (TWC) in December 1989. .

\subsection{Nueces estuary technical advisory committee}

In response to the complaint, the TWC ordered the provision of flows to the estuary in May 1990 and created the Nueces Estuary Technical Advisory Committee (NETAC) in June 1990. The purpose of NETAC is to provide recommendations to develop final operational procedures of the Choke Canyon/Lake Corpus Christi reservoir system pursuant to the special condition requiring environmental flows. The order charges NETAC to collect available data, identify key issues, develop alternative strategies, and recommend a preferred strategy for accomplishing the goals.

The NETAC is composed of stakeholders including resource managers, academic scientists, engineers, advocacy groups, environmental groups, and citizen groups. The NETAC meetings were presided over by a member of the TWC and are typically scientific in content. Over the years, NETAC has received reports on the science supporting environmental flows, created a monitoring plan, and made recommendations to the State regarding changes to the agreed order. Thus, without knowing it, or with this design in mind, a stakeholder driven governance process was created that used science-based information for adaptive management. Between 1990 and the present time (2009) there have been several science and management projects and the City has received requested approval for changes to the original agreed order.

\subsection{The 1995 agreed order}

Based on NETAC recommendations, Texas Natural Resource Conservation Commission (formerly TWC, but now the Texas Commission on Environmental Quality) issued a Final Agreed Order in April 1995 to amend many of the 1992 Agreed Order provisions. A key NETAC finding was based on inflow needs studies carried out jointly by the Texas Parks and Wildlife Department and the Texas Water Development Board indicating that maximum fishery harvest could be sustained with 138,000 ac-ft $\left(17010^{6} \mathrm{~m}^{3}\right)$ per year delivered in a monthly inflows to mimic natural hydrographic conditions in the Nueces Basin, table 1. There were three other important revisions: 1) the minimum mandatory inflows were changed to targeted monthly inflows, 2) the releases were changed to passthroughs, and 3) drought relief was granted in the form of different pass-through requirements based on the reservoir level.

There are important distinctions between the words release, pass-through, and spill. A release is stored water that is let out of a lake to meet downstream water rights and supply raw water to water treatment plants. A pass-through is water 
Table 1: $\quad$ Pass-through targets for the Nueces estuary set in the 1995.

\begin{tabular}{|c|c|c|c|c|}
\hline \multirow{3}{*}{ Month } & \multicolumn{4}{|c|}{ Pass-through Targets (Acre Feet $=1233 \mathrm{~m}^{3}$ ) } \\
\cline { 2 - 5 } & $\begin{array}{c}\text { Capacity } \geq \\
70 \%\end{array}$ & $\begin{array}{c}40 \% \leq \\
\text { Capacity }< \\
70 \%\end{array}$ & $\begin{array}{c}30 \% \leq \\
\text { Capacity }< \\
40 \%\end{array}$ & $\begin{array}{c}\text { Capacity }< \\
30 \%\end{array}$ \\
\hline Jan & 2,500 & 2,500 & 1,200 & 0 \\
\hline Feb & 2,500 & 2,500 & 1,200 & 0 \\
\hline Mar & 3,500 & 3,500 & 1,200 & 0 \\
\hline Apr & 3,500 & 3,500 & 1,200 & 0 \\
\hline May & 25,500 & 23,500 & 1,200 & 0 \\
\hline June & 25,500 & 23,000 & 1,200 & 0 \\
\hline July & 6,500 & 4,500 & 1,200 & 0 \\
\hline Aug & 6,500 & 5,000 & 1,200 & 0 \\
\hline Sept & 28,500 & 11,500 & 1,200 & 0 \\
\hline Oct & 20,000 & 9,000 & 1,200 & 0 \\
\hline Nov & 9,000 & 4,000 & 1,200 & 0 \\
\hline Dec & 4,500 & 4,500 & 1,200 & 0 \\
\hline Total & 138,000 & 97,000 & 14,400 & 0 \\
\hline
\end{tabular}

that has flowed into the reservoir system, up to the monthly target amount, and is let out of Lake Corpus Christi to meet the freshwater inflow requirements to the Nueces Estuary. Thus, if there are inflows to the reservoirs, the City is required to pass-through the target amount based on the level of the reservoir. A spill is water that is let of a lake because the lake is full.

The inflow targets to the estuary can be met by rain, river inflow, return flows, or diversions. Releases, when required to satisfy a targeted pass-through requirement, are made at the end of a month if it is projected that the target flow will not be met by theses other sources. However, this is a pass-through plan and at no time is the City required to release water from system storage to satisfy the estuary target inflow amount if insufficient flows enter the reservoir.

\subsection{The 2001 amendment}

Largely based on the research performed in the Rincon Bayou Demonstration Project [8], the City of Corpus Christi obtained another amendment to the agreed order in April 2001. The main changes were related to revising the drought management measures in the 1995 order. In the 1995 order, the initiation of the drought relief was a solely at the discretion of the City, which means that every time the City wanted to use the drought measures, it required action by the Mayor and City Council. This became a highly politicized issue. In the 2001 amendment, the City is now required to implement drought mitigation measures, such as lawn and outdoor water use restrictions, at the reservoir level amount that provide drought relief. Also, new bathymetric surveys were performed that increased the total water storage capacity by 16,019 ac-ft $\left(19.7510^{6} \mathrm{~m}^{3}\right)$ because of sediment retention. 
In exchange for these benefits the City agreed to 1) reconstruct the Nueces River Overflow Channel to Rincon Bayou, 2) construct a pipeline to convey up to 3,000 ac-ft $\left(3.710^{6} \mathrm{~m}^{3}\right)$ directly to the Nueces Delta, and 3) implement an ongoing monitoring and assessment program to facilitate adaptive management for freshwater flows into the Nueces Estuary.

\section{Discussion and lessons learned}

The experience in the Nueces Estuary has been remarkable because what has been accomplished. The accomplishments are due to three factors: 1) state laws requiring consideration of environmental flows in the water permitting process, 2) using science-based to advise to determine inflow needs, and 3) a stake-holder process including concerned citizens and technical people to provide for adaptive management. This combination of policy, governance, and science is a powerful ecosystem-based management tool.

Although Texas law requires environmental flows, it is not scientifically prescriptive. Consider the following extracts from recent legislature:

- 1985, HB 2: requires: "maintain a sound ecological environment" in Texas bays and estuaries.

- 2001, HB 1629: "maintain the ecological health and productivity of the Matagorda Bay system."

- 2003, SB 1639: requires: "provide for the freshwater inflows necessary to maintain the viability of the state's bay and estuary systems."

- 2007, SB 3: "adequate to support a sound ecological environment and to maintain the productivity, extent, and persistence of key aquatic habitats."

Clearly the first technical task was to define what is meant by "sound ecological environment," "ecological health," "viability of the bay and estuary systems," and "persistence of key aquatic habitats." These are not just fluffy words, and by using the context that the U.S. Environmental Protection Agency has used these words for water quality assessment, it is easy to define them in terms of the general reference frame of "ecological health:"

- Ecological health is assessed by determining if indicators of ecological conditions are in an acceptable range.

- Indicators establish an acceptable range of responses across broad spatial and temporal scales.

- Condition is the status of ecological function, integrity, and sustainability.

- Function is acceptable when the ecosystem provides important ecological processes.

- Integrity is acceptable when biological diversity, species composition, structural redundancy, and functional processes are comparable to that of natural habitats in the same region.

- Sustainability is acceptable when an ecosystem maintains a desired state of ecological. 
Interpreting the legislative language in this way also defines ecological indicators that will work for determining environmental flow needs. Function is ecological processes, e.g., production, trophic links, reproduction. Integrity is community structure and biodiversity, e.g., benthos, nekton, plankton. Sustainability is the provision of ecosystem services, e.g., habitats.

Thus the focus of the monitoring and experimental studies commissioned by the NETAC focus on benthos community structure and diversity (an indicator of integrity), and marsh plant vegetation cover (an indicator of sustainability). After great effort, this focus was understandable to the general public, and today there is much less controversy about water flowing from the dam to the bay.

Since 1990, a process of science-based decision-making and adaptive management has led to: 1) increased and more stable water supply, and 2) environmental restoration and protection. The goal of achieving consensus was accomplished by the blend and balance of science and the stakeholder decisions coming out of the NTEAC process. This approach can be a model for others dealing with issues of environmental flows. However, with climate change potentially altering the water cycle and continued development requiring more water resources, more changes are likely to occur in the future.

\section{Acknowledgements}

This manuscript was partially supported by funding from the City of Corpus Christi, contract number CCC-5133; the Coastal Bend Bays \& Estuaries Program, Inc., contract number 0821; and the Harte Research Institute.

\section{References}

[1] Millennium Ecosystem Assessment, Ecosystems and Human Well Being: Current State and Trends. Findings of the Condition and Trends Working Group, Island Press: Washington DC, 948 pp., 2005.

[2] Cross, R. \& Williams D. (eds), Proceedings of the National Symposium on Freshwater Inflow to Estuaries, U.S. Fish and Wildlife Service, Office of Biological Services, FWS/OBS-81/04, 2 vols., 1981

[3] Montagna, P.A., Alber, M., Doering, P. \& Conner, M.S., Freshwater inflow: Science, Policy, Management. Estuaries 25, pp. 1243-1245, $2002 \mathrm{a}$.

[4] Longley, W.L. (ed), Freshwater Inflows to Texas Bays and Estuaries: Ecological Relationships and Methods for Determination of Needs, Texas Water Development Board and Texas Parks and Wildlife Department, Austin, TX, 386 pp., 1994.

[5] Larkin, T. J. \& Bomar, G.W., Climatic Atlas of Texas. Texas Department of Water Resources. Austin, TX. 151 pp., 1983.

[6] National Oceanic and Atmospheric Administration, Local Climatological Data at Corpus Christi International Airport, 2001-2002. U.S. Department of Commerce, Ashville, NC., 2002. 
[7] Cunningham, A.M, Corpus Christi Water Supply: Documented History 1852-1997. Second Edition. Texas A\&M University- Corpus Christi, Corpus Christi, TX, 588 pp., 1999.

[8] Bureau of Reclamation, Concluding Report: Rincon Bayou Demonstration Project. United States Department of Interior, Bureau of Reclamation, Oklahoma-Texas Area Office, Austin, Texas, 2000.

[9] Asquith, W.H., Mosier, J.G. \& Bush, P.W., Status, Trends and Changes in Freshwater Inflows to Bay Systems in the Corpus Christi Bay National Estuary Program Area. Publication CCBNEP-17, Texas Natural Resource Conservation Commission, Austin, TX, 45 pp., 1997.

[10] http://www.twdb.state.tx.us/data/bays_estuaries/bays_estuary_toc.htm

[11] Montagna, P.A., Kalke, R.D. \& Ritter, C., Effect of restored freshwater inflow on macrofauna and meiofauna in upper Rincon Bayou, Texas, USA. Estuaries 25 pp. 1243-1245, 2002 b.

[12] Palmer, T.E., Montagna, P.A. \& Kalke, R.D., Downstream effects of restored freshwater inflow to Rincon Bayou, Nueces Delta, Texas, USA. Estuaries 25 pp. 1448-1456, 2002.

[13] Alexander, H.D. \& Dunton, K.H., Freshwater inundation effects on Emergent vegetation in a hypersaline salt marsh. Estuaries 25 pp. 14261435, 2002.

[14] Montagna, P.A., Holt, S., Ritter, C., Binney, K. Herzka, S. \& Dunton, K., Characterization of Anthropogenic and Natural Disturbance On Vegetated and Unvegetated Bay Bottom Habitats in the Corpus Christi Bay National Estuary Program Study Area. Publication CCBNEP-25, Texas Natural Resource Conservation Commission, Austin, TX, 130 pp., 1998.

[15] Ward, G.H., Irlbeck, M.J., \& Montagna, P.A., Experimental river diversion for marsh enhancement. Estuaries 25, pp. 1416-1425, 2002.

[16] Hopkins S.H. \& Andrews, J.D., Rangia cuneata on the east coast: thousand mile range extension, or resurgence? Science 167, pp. 868-869, 1970.

[17] Wolfe, D.A. \& Petteway, E.N., Growth of Rangia cuneata Gray. Chesapeake Science 9, pp. 99-102, 1968.

[18] Dunton, K. H. \& Hill, E.M., Allison Wastewater Treatment Plant Effluent Diversion Demonstration Project. Volume I: Executive Summary. University of Texas - Marine Science Institute Port Aransas, Texas and Texas A\&M University - Corpus Christi, Center for Coastal Studies, Corpus Christi, TX, 2005.

[19] Alexander H. D. \& Dunton, K.H., Treated wastewater effluent as an alternative freshwater source in a hypersaline salt marsh: impacts on salinity, inorganic nitrogen, and emergent vegetation. Journal of Coastal Research 22, pp. 377-392, 2006.

[20] Forbes M.G., Alexander, H.D., \& Dunton, K.H., Effects of pulsed riverine versus non-pulsed wastewater inputs of freshwater on plant community structure in a semi-arid salt marsh. Wetlands 28, pp. 984-994, 2008. 